Institute of Internet and Intelligent Technologies

Vilnius Gediminas Technical University

Saulètekio al. 11, 10223 Vilnius, Lithuania

http://www.isarc2008.vgtu.lt/
The $25^{\text {th }}$ International Symposium on Automation and Robotics in Construction

June 26-29, 2008

ISARC-2008

\title{
DETERMINATION OF RATIONAL METHOD FOR RESOLUTION OF DISPUTES WITH THE HELP OF MULTI-CRITERIA NEGOTIATION DECISION SUPPORT SYSTEM FOR REAL ESTATE
}

\author{
Arturas Kaklauskas \\ Department of Construction Economics and \\ Property management \\ Vilnius Gediminas Technical University \\ Sauletekio av. 11, LT-10223 Vilnius, Lithuania \\ arturas.kaklauskas@st.vgtu.lt
}

\author{
Violeta Kersuliene \\ Office of Legal Affairs \\ Vilnius Gediminas Technical University \\ Sauletekio av. 11, LT-10223 Vilnius, Lithuania \\ kvioleta@adm.vgtu.lt
}

\author{
Vita Urbanaviciene \\ Department of Construction Economics and \\ Property management \\ Vilnius Gediminas Technical University \\ Sauletekio av. 11, LT-10223 Vilnius, Lithuania \\ vitaur@st.vgtu.lt
}

\begin{abstract}
There are quite many researches dedicated to application of Internet based decision support systems for solution of various tasks of construction process, but there is a lack of feasibility studies and practical application to solve legislative tasks. In order to assess dispute resolution methods of economically, socially and/or from other point of views, it is necessary to apply methods for assessing solutions according to multiple indices. For this purpose one can apply the NDSS-RE. With the help of the NDSS-RE, a user can obtain essential data and information and then to analyse in detail the problem to be solved in various (desired) aspects. The said system evaluates possible solution alternatives from various sides and selects the most efficient versions, thus allowing the user to make a rational decision. And namely the determination of rational method to solve dispute is the purpose of this work.
\end{abstract}

\section{KEYWORDS}

Dispute resolution, decision support system 


\section{INTRODUCTION}

Determination of rational method for dispute resolution is an issue of special relevance when disputes arise among participants of construction process. This is so because of a few reasons: first of all, resolution of disputes among participants of construction process not rarely required complex legal, technological, engineering, economic, etc. knowledge; secondly, disputes among construction process participants frequently stop development of construction projects, where time of special value, thereby increasing construction costs; thirdly, completion of construction process in contemporary society is no longer linked with completion of construction works, since a builder is responsible for warranty elimination of defects and for damage to third persons because of construction works, and therefore for construction process participants it is very important that their disputes have a minimum impact to their amicable relations inn future.

Disputes of construction process participants, often evolving into major conflicts, are characteristic to all the major construction projects $[1 ; 2]$. Moreover, these disputes have a specific feature to strongly influence implementation of construction projects. Therefore it is not a coincidence that many authors examine it as a separate sort of disputes $[3 ; 4 ; 5 ; 6$; $7 ; 8]$.

Participants of construction process, when encountering a conflict, must decide on the best solution: to entrust dispute resolution to courts, to attempt resolving it by means of negotiations, or maybe there is a possibility to entrust the dispute resolution to arbitration or mediation? By selecting a proper method to resolve a specific dispute, parties not only would be able to save much time, avoid emotional stresses and undesired publicising of problems, but frequently would also avoid large financial costs related to litigation in court and would not preclude further cooperation, in absence of which successful implementation of construction projects is not possible.

\section{APPLICATION OF DECISION SUPPORT SYSTEMS FOR SELECTION OF DISPUTE RESOLUTION METHOD}

To solve various legal, technological, management etc. tasks, decision support systems are globally used with success already for a few decades, which systems help users to analyse possible resolution versions and offer the best (most rational) decisions. Application of decision support systems for resolution of various legal issues is analysed in works of many authors $[3 ; 4 ; 9 ; 10 ; 11 ; 12 ; 13]$. In spite of this fact, there is a lack of academic researches that would substantiate decisions of participants of construction process when selecting the most rational dispute resolution method and pave the road for installation of computer technologies allowing to resolve their mutual disputes with lowest time, financial, emotional etc. costs.

Parties of a dispute, when aware of pros and contras of one dispute resolution method or another, understand that litigation in court is not panacea for all the problems, or in other words, it is not the sole way to resolve disputes. Such knowledge allows selecting, reasonably and deliberately, the most suitable resolution method for a particular dispute court litigation, arbitration, mediation, reconciliation, etc. Construction process participants, when attempting to find which method of dispute resolution is the most expedient one, will unavoidably meet the decision selection procedure. Since making of legal decisions is usually based on logical analysis of circumstances and facts related to the dispute, for substantiation of such decisions one could successfully apply mathematical calculations [14]. Thus for determination of rational method for resolution of disputes among construction process participants, we may apply decision making systems designed on the basis of these calculations.

There are no systems satisfying needs of construction process participants that could be applied for selection of dispute resolution method and dispute resolution yet created in Lithuanian. Therefore, a question arises concerning causes that impede development of such systems in the sphere of dispute resolution. We can agree with authors who state that so far none of known methods of 
reasoning modeling can model the process of legal reasoning with a sufficient precision. Besides that, formalisms of legal knowledge representation are hard for comprehension for jurists, so it remains unclear how they can approve and legalize legal knowledge bases created on the basis of such formalisms.

Majority of decision makers try to find the most costeffective solutions, therefore, majority of decision support systems process and present only economic information and apply economic models for decisions [15]. While participants of construction process select the most rational method of dispute resolution, other criteria play an important role as well - time costs, confidentiality, preservation of friendly relationship, etc. Seeking to describe alternatives of investigated methods of dispute resolution with more detail, it is necessary to describe them basing on economic, legal, social, technical and other qualitative and quantitative indexes.

Specialized negotiation decision support systems for selection of the most effective dispute resolution method and dispute resolution in expert sub-system should have four main rules and procedure categories:

1. Creation of alternatives of dispute resolution.

2. Formation of criteria systems describing alternatives, meanings and importance. This category includes sets of rules that present a criteria system describing alternative, criteria meanings and importance for formed alternatives.

3. Having set priority, degree of usefulness and value of alternatives, rules of sub-system would offer the alternatives that are worth to be analyzed further and why. The main goal of set of such rules is to set the most rational options of dispute resolution basing on criteria specified below:

- Sum of money that a party is ready to pay for dispute resolution.

- $\quad$ Priority and degree of usefulness of options of dispute resolution.

- Reliability of alternatives basing on precedents of analogical disputes.
4. Creation of detailed and motivated negotiation e-mail message and Internet web-site for party of a dispute. By the use of information received during previous calculations and rules and procedures set in advance, expert sub-system would prepare one negotiation e-mail message for each of the users, which would include a reasonable offer to select one of dispute resolution methods specified in alternatives. This e-mail message would present links to calculations done.

The scientists of Vilnius Gediminas Technical University created Multiple Criteria Web-based Negotiation Decision Support System for Real Estate (NDSS-RE). Modules of alternative creation, multi-criteria analysis and negotiation are used by NDSS-RE, which allow the users evaluating own needs and possibilities and understand importance of comprising, assisting in seeking for mutual benefit. Functions performed by NDSS-RE:

Search for alternatives by the use of standardized data presentation forms.

Finding out alternatives and making initial comparative tables. Consumers specify requirements and constraints and the System queries the information of specific real estate from a number of online brokers. The System performs the tedious, time-consuming, and repetitive tasks of searching databases, retrieving and filtering information and delivering the information back to the user. Results of a search of specific real estate are submitted in initial comparative table. By submission such a display, the multiple criteria comparisons can become more effectively supported.

Multiple criteria analysis of alternatives. While going through the purchasing decision process a consumer must examine a large number of alternatives, each of which is surrounded by a considerable amount of information (economic, quality, technical, legal, and other factors). Following on from the gathered information the priority and utility degree of alternatives is then calculated. During this analysis the buyer (broker) determines the initial priority, utility degree and market value of the analysed real estate alternatives. 
Negotiations based on real calculations. During online-negotiations the buyer (seller) with the help of NDSS-RE may perform real calculations. According to the results received the final comparative table is developed.

Determination of the most rational real estate purchase variant on the ground of characteristics describing effectiveness of the analysed alternatives (priority, utility degree and market value). Following on the developed final comparative table the multiple criteria analysis and selection of the best real estate buying version are being carried out using NDSS-RE.

Search for alternatives by the use of standardized data presentation forms.

Presentation of recommendations. On this stage the system can offer to increase or reduce the price of an object being sold with consideration of object's popularity (this is set having assessed interest of users in object's system).

Considering that this system is adjusted for assessment of various alternatives and determination of rational option, it can be successfully applied seeking to set rational dispute resolution method for construction process participants.

\section{INDEXES CHARACTERIZING DISPUTE RESOLUTION METHODS AND DETERMINATION OF THEIR VALUES}

In order to determine rational dispute resolution method of construction process participants it is necessary to enter possible alternative of dispute resolution methods into system's data basis, to describe them with qualitative or quantitative $\mathrm{c}$ characteristics and set criteria priorities.

As survey of "Norcous \& Partners" layers' office and Vilnius Commercial Arbitrage Court [15] demonstrate, respondents indicate quite a number of criteria that they consider to be more or less important in selection of dispute resolution method: expedition of dispute resolution, price of dispute resolution, possibilities to appeal against decision, confidentiality, freedom of parties' disposal of dispute, preservation of friendly relationship, satisfaction of parties with dispute resolution, securing compulsory implementation, as well as acknowledgement of decisions abroad, authority of person who is resolving a dispute, advice of a lawyer, customs predominating in society, advice from friends, attention to parties' opinion, etc.

Knowing importance of indexes, value of each of them can be determined as follows [15]:

the most important index gets chosen (in case under investigation - expedition of dispute resolution) $X_{\text {ger }}$

the best value of index under investigation receives value of 1 point importance $\left(X_{\text {ger }}=1\right)$;

number of per cent $\left(p_{i}\right)$ of value of remaining indexes $\left(X_{i}\right)$ that are worse than the best one is determined $\left(X_{\text {ger }}=1\right)$;

indexes values receive relative values $\left(X_{i}=1-p_{i}\right.$ /100);

relative values of all indexes $\left(q_{i}\right)$ are recalculated so that their sum would equal one:

$\sum_{i=1}^{t} q_{i}=1 ; \quad \mathrm{i}=1,2, \ldots, \mathrm{t}$

Since the respondents indicated a large number of various factors [16] that condition selection of dispute resolution method, in order to select rational dispute resolution method of construction process participants with sufficient precision a smaller number of indexes can be assessed. Authors offer to perform calculations only according to 10 most important indexes (Table 1).

Results of calculation performed (expedition of dispute resolution $\left(q_{1}\right)$, price of dispute resolution $\left(q_{2}\right)$, possibilities to appeal against decision due essence of dispute $\left(q_{3}\right)$, possibilities to appeal against decision due to procedural violations $\left(q_{4}\right)$, securing confidentiality $\left(q_{5}\right)$, acknowledgement of decisions abroad $\left(q_{6}\right)$, freedom of parties' disposal of dispute $\left(q_{7}\right)$, preservation of friendly relationship $\left(q_{8}\right)$, authority of person who is resolving a dispute $\left(q_{9}\right)$, satisfaction of parties with dispute resolution $\left.\left(q_{10}\right)\right): q_{1}=0,25 ; q_{2}=0,21 ; q_{3}=0,09 ; q_{4}=0,09 ; q_{5}=0,1$; $q_{6}=0,07 ; q_{7}=0,03 ; q_{8}=0,03 ; q_{9}=0,08 ; q_{10}=0,05$. 
Table 1. Parameters of Indices Characterising Methods for Solution of Customer-Contractor Disputes

\begin{tabular}{|c|c|c|c|c|c|}
\hline \multirow[b]{2}{*}{ Index } & \multirow{2}{*}{$\begin{array}{l}\text { Unit of } \\
\text { measurement }\end{array}$} & \multirow{2}{*}{$\begin{array}{c}\operatorname{Min} / \\
\max \end{array}$} & \multicolumn{3}{|c|}{ Alternative } \\
\hline & & & Court $\left(V_{1}\right)$ & $\begin{array}{l}\text { Arbitra- } \\
\text { tion }\left(\mathrm{V}_{2}\right)\end{array}$ & $\begin{array}{l}\text { Media- } \\
\text { tion }\left(\mathrm{V}_{3}\right)\end{array}$ \\
\hline Expedition of dispute examination & Months & $\min$ & 24 & 3 & 3 \\
\hline $\begin{array}{l}\text { Price of dispute resolution (when dispute } \\
\text { amount is } 100000 \mathrm{Lt})\end{array}$ & $\mathrm{Lt}$ & $\min$ & $\begin{array}{l}6000 \text { (when } \\
\text { litigating in } 2 \\
\text { justices) }\end{array}$ & 6490 & 3000 \\
\hline $\begin{array}{l}\text { Possibility to appeal against decision } \\
\text { concerning dispute essence }\end{array}$ & $1 / 0$ & $\max$ & 1 & 0 & 0 \\
\hline $\begin{array}{l}\text { Possibility to appeal against decision } \\
\text { concerning procedural violations }\end{array}$ & $1 / 0$ & $\max$ & 1 & 1 & 0 \\
\hline Assurance of confidentiality & $1 / 0$ & $\max$ & 0 & 1 & 1 \\
\hline Acknowledgement of decision abroad & $1 / 0$ & $\max$ & 1 & 1 & 0 \\
\hline Freedom of parties to handle the dispute & Scores $(1-3)$ & $\max$ & 1 & 3 & 3 \\
\hline Preservation of amicable relations & Scores $(1-3)$ & $\max$ & 1 & 2 & 3 \\
\hline Authority of person solving the dispute & Scores $(1-3)$ & $\max$ & 1 & 3 & 3 \\
\hline Satisfaction with outcome of dispute & Scores $(1-3)$ & $\max$ & 1 & 2 & 3 \\
\hline
\end{tabular}

Table 2 Results of multiple criteria evaluation of alternatives of disputes' resolution

\begin{tabular}{|c|c|c|c|c|c|c|c|}
\hline No. & Criteria under evaluation & $\begin{array}{l}\text { Measuring units } \\
\text { of criteria }\end{array}$ & * & $\begin{array}{l}\text { Weights of } \\
\text { criteria }\end{array}$ & 1063 & 1064 & 1065 \\
\hline 1 & Expedition of dispute examination & Months & - & 0,2500 & 0,2000 & 0,0250 & 0,0250 \\
\hline 2 & $\begin{array}{l}\text { Price of dispute resolution (when } \\
\text { dispute amount is } 100000 \mathrm{Lt})\end{array}$ & $\mathrm{Lt}$ & - & 0,2100 & 0,0813 & 0,0880 & 0,0407 \\
\hline 3 & $\begin{array}{l}\text { Possibility to appeal against decision } \\
\text { concerning dispute essence }\end{array}$ & $1 / 0$ & + & 0,0900 & 0,0900 & 0,0000 & 0,0000 \\
\hline 4 & $\begin{array}{l}\text { Possibility to appeal against decision } \\
\text { concerning procedural violations }\end{array}$ & $1 / 0$ & + & 0,0900 & 0,0450 & 0,0450 & 0,0000 \\
\hline 5 & Assurance of confidentiality & $1 / 0$ & + & 0,1000 & 0,0000 & 0,0500 & 0,0500 \\
\hline 6 & Acknowledgement of decision abroad & $1 / 0$ & + & 0,0700 & 0,0350 & 0,0350 & 0,0000 \\
\hline 7 & $\begin{array}{l}\text { Freedom of parties to handle the } \\
\text { dispute }\end{array}$ & Scores $(1-3)$ & + & 0,0300 & 0,0043 & 0,0129 & 0,0129 \\
\hline 8 & Preservation of amicable relations & Scores (1-3) & + & 0,0300 & 0,0050 & 0,0100 & 0,0150 \\
\hline 9 & Authority of person solving the dispute & Scores $(1-3)$ & + & 0,0800 & 0,0114 & 0,0343 & 0,0343 \\
\hline 10 & Satisfaction with outcome of dispute & Scores $(1-3)$ & + & 0,0500 & 0,0083 & 0,0167 & 0,0250 \\
\hline \multicolumn{5}{|c|}{ Total sum of maximizing normalized balanced rates $S_{+j}$} & 0.199 & 0.2039 & 0.1372 \\
\hline \multicolumn{5}{|c|}{ Total sum of minimizing normalized balanced rates $S_{-j}$} & 0.2813 & 0.113 & 0.0657 \\
\hline \multicolumn{5}{|c|}{ Object's significance $Q_{j}$} & 0.2582 & 0.3513 & 0.3906 \\
\hline \multicolumn{5}{|c|}{ Object's utility degree $\mathrm{N}_{\mathrm{j}}$} & $66 \%$ & $90 \%$ & $100 \%$ \\
\hline \multicolumn{5}{|c|}{ Object's priority } & 3 & 2 & 1 \\
\hline \multicolumn{5}{|c|}{ Supply price } & 6,00 & 6,49 & 3,00 \\
\hline \multicolumn{5}{|c|}{ Market value } & 0,43 & 6,49 & 3,00 \\
\hline \multicolumn{5}{|c|}{ Mass Appraisal Value } & 0,00 & 0,00 & 0,00 \\
\hline
\end{tabular}




\section{MULTI-CRITERIA ASSESSMENT OF DISPUTE RESOLUTION METHODS WITH A HELP OF NDSS-RE}

As it was already mentioned, NDSS-RE is adjusted for assessment of various alternatives and determination of a rational option, therefore, determination of rational dispute resolution method of construction process participants can be entrusted to this system.

According to values of indexes presented in Table 1 NDSS-RE performs multi-criteria assessment of alternatives and determines degree of usefulness of resolution methods (Table 2 ):

As it can be seen according to multi-criteria assessment of alternatives presented in Table 2, the method of mediation should be considered as the most effective method for resolution of disputes according to set criteria value.

Considering that in case of conflicts originating between construction process participants, parties frequently cannot resolve disputes constructively due to emotions accumulated, weak skills in wellgrounded stating of own position, dispute resolution can be facilitated by negotiation decisions support systems, with a help of which construction process participants could resolve disputes online.

Besides that, recently with increased frequency we face instigations of international organizations to create effective online dispute resolution conditions, so that parties of a dispute could have a possibility to resolve disagreements originating without appealing to state institutions.

\section{CONCLUSIONS}

It is determined that the Internet provides excellent possibilities for determination of rational dispute resolution method. In each specific case having analyzed negative and positive qualities of various dispute resolution methods perspective of litigation in court and applying other dispute resolution methods can be assessed. Such knowledge allows perform well-grounded and conscious selection of the most effective method for specific dispute resolution litigation in court, arbitrage, mediation, etc.
It is proved that for successful selection of rational method for dispute resolution NDSS-RE can be applied. Multi-criteria alternative assessment made with the help of this system according to determined significance of indexes, mediation should be considered as the most effective dispute resolution methods.

NDSS-RE system can be applied in practical implementation of alternative dispute resolution in virtual environment.

\section{REFERENCES}

[1] Vaaland, T. I. Improving project collaboration: start with the conflicts. International Journal of Project Management, Vol. 22, 2004, p. 447-454.

[2] Arditi, D.; Tokdemir, O. B. Using Case-Based Reasoning to Predict the Outcome of Construction Litigation. Computer-Aided Civil and Infrastructure Engineering, 14, 1999, p. 385-393.

[3] Castell, S. The role of the IT expert witness in software and systems development/implementation contract disputes and litigation. Computer Law \& Security Report, Vol. 19, No. 3, 2003, p. 228- 231.

[4] Iyer, K. C.; Chaphalkar, N. B.; Joshi, G. A. Understanding time delay disputes in construction contracts. International Journal of Project Management, 2007, doi:10.1016/j.ijproman.2007.05.002.

[5] Odeh, A. M.; Battaineh, H. T. Causes of construction delay: traditional contracts. International Journal of Project Management, Vol. 20, 2002, p. 67-73.

[6] Assaf, S. A.; Al-Hejji, S. Causes of delay in large construction projects. International Journal of Project Management, 2006, Vol 24, p. 349-357.

[7] Chen, J. H.; Hsu, S. C. Hybrid ANN-CBR model for disputed change orders in construction projects. Automation in Construction, 2007, Vol 17, p. 56-64.

[8] Ginevičius, R.; Podvezko, V.; Andruškevičius A. Technological evaluation of construction systems using AHP method. Ükio technologinis ir ekonominis vystymas, 2004, Nr. 4, p. 135-140.

[9] Kaklauskas, A.; Urbanavičienė, V. Intelcity and multiple citeria web-based negotiation decision support system for real estate. Ükio technologinis ir ekonominis vystymas, 2005, Nr. 3, p. 183-189.

[10] Keršulienė V., Urbanavičienė V. Selection of economy based methods for resolution of disputes originated between the client and contractor. 9th 
International Conference: Modern building materials, structures and techniques, Vols 1-3, p. 287-292, 2008.

[11]Zavadskas, E. K.; Simanauskas, L.; Kaklauskas, A. Decision support systems in construction .VGTU: Technika, 1999, $236 \mathrm{p}$.

[12] Ustinovichius, L.; Barvidas, A.; Ashikmin, I. Verbal analysis of DSS unicombos for engineering project models. Selected papers of the $9^{\text {th }}$ International Conference, held on May 16-18, 2007, Vilnius, 2007, p. 392-400.

[13] Keršulienè, V. Possibilities of client and contractors disputes settlement at the pretrial stage. Ūkio technologinis ir ekonominis vystymas 2007, XIV t., Nr. 2.

[14] Norcous \& Partners. Resolution of disputes: executive letter of Europe. Bulletin: RoschierRaidla, 2007, gegužè, 8 p.

[15]Zavadskas, E. K.; Turskis, Z.; Vilutienè, T. Simulation of Multi - Criteria Selection of Buildings Maintenance Contractor Using the Game Theory. Computer Modelling and New Technologies, 2005, Vol 9, No 2, p. 7-16. 